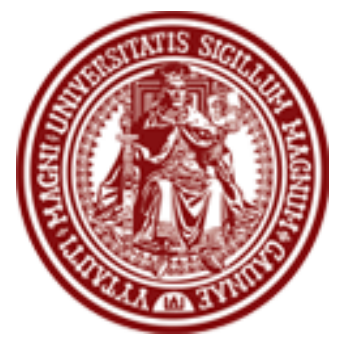

BALTIC JOURNAL OF LAW \& POLITICS

VOLUME 4, NUMBER 1 (2011)

ISSN 2029-0454

http://www.versita.com/bjlp

Cit.: Baltic Journal of Law \& Politics 4:1 (2011): 27-51

DOI: $10.2478 / \mathrm{v} 10076-011-0002-7$

\title{
ACCESSIBILITY OF HIGHER EDUCATION: THE RIGHT TO HIGHER EDUCATION IN COMPARATIVE APPROACH
}

\author{
Aurelija Pūraitè \\ Assistant Professor; Dr. \\ Mykolas Romeris University Faculty of Public Safety (Lithuania) \\ Contact information \\ Address: V. Putvinskio 70, LT - 44211 Kaunas, Lithuania \\ Phone: (+370 37) 303655 \\ E-mail address: aurelija_puraite@yahoo.com
}

Received: January 10, 2011; reviews: 2; accepted: May 27, 2011.

\begin{abstract}
At present there is an unprecedented demand for and a great diversification in higher education, as well as an increased awareness of its vital importance for socio-cultural and economic development. The complexity of the right to education is especially at issue while discussing the right to higher education, which on a national level is non-compulsory, even though the number of people who have acquired higher education during the second half of the twentieth century has tripled. Therefore the object of this research is the content and scope of the concept of accessibility of higher education. The definition of the obligations of the states prescribed in the international and national legal instruments in respect to the right to higher education, the analysis of the standards and principles of the accessibility of the right to higher education, the discussion of the most often social, economic and legal causes for violations of the higher education accessibility, and the identification of the problems of higher education accessibility in Lithuania with respect to constitutional provisions are presented in this research.
\end{abstract}

\section{KEYWORDS}

Higher education, accessibility, constitutional provision, free higher education 


\section{INTRODUCTION}

Relevance of the research. The right to education (and respectively, the right to higher education) is commonly identified as an economic, social and cultural right and that influences the interpretation and implementation of this right as an economic, social and cultural right. Relative and indefinite "according to its potential" obligations and requirements related to the "consistent", "progressive" implementation of this right are usually imposed on governments.

At present there is unprecedented demand for and great diversification in higher education as well as increased awareness of its vital importance for sociocultural and economic development. However, the right to higher education in many countries becomes more and more theoretical than realized in practice which paradoxically transforms the essence of the right itself. One of the principal challenges is that the demand for higher education is growing faster than the ability or willingness of governments to provide public resources or legal measures adequate to meet this demand.

The complexity of the right to education is especially at issue when discussing the right to higher education, which at the national level is non-compulsory (as opposed to, for example, elementary or secondary education), even though the number of people who have acquired higher education during the second half of the twentieth century has tripled (based on data from 1950, out of 260 million people, $82 \%$ had acquired only an elementary education; $16 \%$ - secondary; and only $3 \%$ higher; in 2000, out of all literate 1 billion 155 million people, 58\% had acquired only secondary education; $34 \%$ - secondary; $8 \%$ - higher). ${ }^{1}$ Based on data from 2006, about 122 million students were enrolled in higher education institutions. ${ }^{2}$

The object of the research. The object of this research is the content and scope of the concept of accessibility of higher education.

The aim of this research is to disclose the content and the scope of the accessibility of the right to higher education and to reveal possible obstacles for the realization of this right.

In order to achieve the determined aim, further tasks are set:

- to define the obligations of the states prescribed in the international and national legal instruments with respect to the right to higher education;

\footnotetext{
${ }^{1}$ World Education Report 2000. The Right to Education. Towards Education for all Throughout Life (Paris: UNESCO Publishing, 2000), p. 54.

2 EFA Global Monitoring Report 2009. Overcoming inequality: why governance matters (UNESCO Publishing, Oxford University Press, 2009), p. 89// http://www.unesco.org/en/efareport/reports/2009governance/ (accessed November 7, 2010).
} 
- $\quad$ to discover and analyze the standards and principles of the accessibility of the right to higher education;

to present, define, and discuss the most usual social, economic, and legal causes for violations of higher education accessibility;

- $\quad$ to identify the problems of higher education accessibility in Lithuania with respect to the constitutional provisions.

Methodology of the Research. In the course of reaching the objective of the research both theoretical and empirical methods of the scientific research were employed, i.e. methods of comparative, systemic analysis, analytical-critical, linguistic, and also methods of documentary analysis and generalization were used.

\section{ACCESSIBILITY OF HIGHER EDUCATION IN INTERNATIONAL AND} REGIONAL LEGAL DOCUMENTS

All legal provisions of international and regional treaties as well as national level legal acts usually describe the right to higher education as requiring "equal access on the basis of capacities". The right to higher education was first mentioned in the Universal Declaration of Human Rights (adopted and declared by the United Nations Assembly General on December 10, 1948, Resolution 217 A (III) ) ${ }^{3}$ Article 26 which states that "Everyone has the right to education. Education shall be free, at least in the elementary and fundamental stages. Elementary education shall be compulsory. Technical and professional education shall be made generally available and higher education shall be equally accessible to all on the basis of merit. "It should be reminded that only a small minority of people had the tangible possibility to acquire any kind of education at the time when the Declaration was adopted, and more than half of the adult population of the world was unable to read. ${ }^{4}$ Therefore, it was extremely important to set imperative obligations related to implementation of at least elementary education to the state parties, as well as to empower the states to adopt all possible legal and administrative measures for maximizing the opportunity for compulsory and free education and higher education accessible to all. It is important to also note that the right to education (including higher education) was immediately comprehended not only by its quantitative measures, but also by implied qualitative requirements which, however, carry a certain amount of ambiguity and indefiniteness.

The provisions of the Universal Declaration of Human Rights were also confirmed in other fundamental international documents for protection of human

\footnotetext{
${ }^{3}$ Universal Declaration of Human Rights, Official Gazette (2006, no. 68-2497).

${ }^{4}$ World Education Report 2000, supra note 1, p. 17.
} 
rights - UNESCO Convention Against Discrimination in Education of $1960,{ }^{5}$ International Covenant on Economic, Social and Cultural Rights of 1966, ${ }^{6}$ Convention on the Rights of the Child of $1989 .{ }^{7}$ The right to higher education in these documents is interpreted very similarly, i.e., states are obligated to provide equal opportunities to acquire higher education for all, based on individual capacity.

The International Covenant on Economic, Social and Cultural Rights (adopted December 16, 1966). Paragraph 2 of Article 13 amplifies the general right to education with references to primary education ("which shall be compulsory and available free to all"), secondary education ("in its different forms", "generally available and accessible to all by every appropriate means, and in particular, by the progressive introduction of free education"), higher education (to be made "equally accessible to all, on the basis of capacity"), and "fundamental education" (for those who have not received or completed primary education).

UNESCO Convention against Discrimination in Education (adopted December 14, 1960). Article 4: The States Parties to this Convention undertake "to make primary education free and compulsory; make secondary education in its different forms generally available and accessible to all; make higher education equally accessible to all on the basis of individual capacity."

Convention on the Rights of the Child (adopted November 20,1989). Articles 28-30. The obligations of States parties in relation to primary, secondary, and fundamental education are not identical. States are obliged to "make primary education compulsory and available free to all", to "encourage the development of different forms of secondary education, make them available and accessible to every child, and take appropriate measures such as the introduction of free education and offering financial assistance in case of need", and to "make higher education accessible to all on the basis of capacity by every appropriate means".

The most important guidelines for the content of the right to education, forming the qualitative measures and specifying the obligations of the states with respect to this right were for the first time established in the International Covenant on Economic, Social and Cultural Rights. Education in all forms and at all levels must exhibit the following features: availability, meaning that there must be functioning educational institutions and that programs must be available in sufficient quantity within the jurisdiction of the State; states must ensure free and compulsory good quality education available for all children up to a defined age minimum with safe schools and appropriate infrastructure and facilities, especially

\footnotetext{
${ }^{5}$ UNESCO Convention Against Discrimination in Education, 429 UNTS 93 //

http://www.unesco.org/education/pdf/DISCRI_E.PDF (accessed June 8, 2010).

6 The International Covenant on Economic, Social and Cultural Rights, Official Gazette (2002, no. 773290).

${ }^{7}$ Convention on the Rights of the Child, Official Gazette (1995, no. 60-1501).
} 
trained teachers; accessibility-which has three overlapping dimensions: nondiscrimination, physical accessibility and economic accessibility; it obligates the elimination of any discrimination on the basis of internationally prohibited grounds: legal and administrative barriers, elimination of ethnicity, economic status, disability, gender obstacles; education must be free and physically accessible; and acceptability and adaptability, whereby education must be flexible so that it may adapt to the needs of changing societies and communities and respond to the needs of students within their diverse social and cultural settings; acceptability includes parental choice of education for their children, enforcement of minimal standards (quality, safety, environmental health); adaptability imposes the obligation to ensure that education is adaptable to the child's specific situation and ability (especially for minority, indigenous, working children, children with disabilities, child migrants). This conceptual framework is the minimum standard and at the same time, the goal implementing the right to education throughout the world.

Another international document precisely related to evaluation of the complexity of higher education and setting forth new measures must be noted World Declaration on Higher Education For The Twenty - First Century: Vision and Action of $1988,{ }^{8}$ adopted by the World Conference Regarding Higher Education, which took place within the scope of UNESCO on October 9, 1998. The Declaration discusses and analyzes in detail many aspects of higher education: the mission of higher education; its liability and functions; the problems of accessibility of higher education; the development of equal opportunities and discrimination elimination tendencies; necessity of the correlation of studies with academic research; the complexity of innovations; the inter-disciplinary aspect and diversity of studies; the necessity for an innovative educational process and its concept ; and the concept of the quality of higher education and its requirements are discussed. A strong necessity for alternative financing of higher education institutions is noted, as well as their management reform, based on innovative methods; recommendations to state parties are provided.

The Declaration stresses that accessibility to higher education should be based on the capacity, effort, commitment and perseverance of those seeking higher education, as well as ensured at any stage of life by legalizing a "life-long learning" scheme whereby everyone could acquire or supplement their education according to individual needs and capabilities. Therefore, discrimination in any form (racial, economical, social, cultural) while ensuring the right of accessibility to

\footnotetext{
8 World Declaration on Higher Education For The Twenty - First Century: Vision and Action and Framework For Priority Action For Change and Development in Higher Education. 1998 // http://www.unesco.org/education/educprog/wche/declaration_eng.htm (accessed November 4, 2010).
} 
higher education is forbidden (Article 3 of the Declaration). The diversification of the models and the criteria for the acceptance of higher education, according to Article 8 of the Declaration, should ensure a growing international demand for higher education and optimize, as well as expand, the implementation model of higher education accessibility to a wider subject range.

International legal documents that oversee the right to higher education are supplemented by legal instruments at regional levels that empower persons to defend their respective breached rights at the regional level. There are a large number of regional documents related to the protection of human rights, yet only several of those directly oversee the right to higher education-or at least partially stress this right-in the general context of the right to education. Regional documents place more focus on the specific cultural, religious, or moral aspects of the protection of human rights in a specified geographical region; therefore, it is assumed that implementation of the latter should not raise the disapproval of state parties. Albeit, the protection and implementation problems of the rights overseen by the regional human rights documents are also at issue just as they are when applying international documents. This could be explained by the multi-cultural and multi-religious environments in almost all regions of the world - Africa, the Continent of Americas, Asia, as well as recent Europe. Therefore, "what is perceived as indisputable truth and non-negotiable Standard of behavior in one culture, may simply be comprehended as a recommendation or advice in other cultures." ${ }^{9}$ When discussing higher education, the relativity of various human rights is witnessed by the number of people who have acquired higher education in each region (Table No. $1)^{10}$, and that is dependent not only on the economic capacity of a certain region, but also on respective traditions, culture, mentality, or religious convictions.

THE NUMBER OF PERSONS WHO HAVE ACQUIRED HIGHER EDUCATION DURING 1950 2000 M. (MILLIONS)

Table 1

\begin{tabular}{|l|c|c|c|c|c|c|}
\hline Region & $\begin{array}{c}\text { Year } \\
1950\end{array}$ & Year 1960 & Year 1970 & Year 1980 & Year 1990 & $\begin{array}{c}\text { Year } \\
2000\end{array}$ \\
\hline Africa & 0,1 & 0,2 & 0,5 & 1,5 & 2,9 & 4,8 \\
\hline $\begin{array}{l}\text { Asia / } \\
\text { Oceania }\end{array}$ & 1,2 & 3,2 & 7,4 & 14,6 & 23,9 & 36,1 \\
\hline Europe & 2,5 & 4,5 & 9,0 & 16,4 & 18,9 & 21,8 \\
\hline $\begin{array}{l}\text { Latin } \\
\text { America / } \\
\text { The }\end{array}$ & 0,3 & 0,6 & 1,6 & 4,9 & 7,3 & 9,4 \\
\hline
\end{tabular}

\footnotetext{
9 Jessica Almqvist, Human Rights, Culture and the Rule of Law (Oxford and Portland, 2005), p. 94.

${ }^{10}$ World Education Report 2000, supra note 1, p. 67.
} 


\begin{tabular}{|l|c|c|c|c|c|c|}
\hline Caribbean & & & & & & \\
\hline $\begin{array}{l}\text { North } \\
\text { America }\end{array}$ & 2,4 & 3,7 & 9,5 & 13,5 & 15,6 & 16,0 \\
\hline $\begin{array}{l}\text { Total in } \\
\text { the world }\end{array}$ & 6,5 & 12,1 & 28,1 & 51,0 & 68,6 & 88,2 \\
\hline
\end{tabular}

In all fundamental regional documents - European Convention on Protection of Human Rights and Fundamental Freedoms ${ }^{11}$ (1950) and its First Protocol ${ }^{12}$ (1952), European Social Charter ${ }^{13}$ (1961), Charter of Fundamental Rights of European Union ${ }^{14}$ (2000), The African Charter on the Rights and Welfare of the Child ${ }^{15}$ (1999), African Charter on Human and Peoples' Rights ${ }^{16}$ (1981), American Convention on Human Rights ${ }^{17}$ (1978), The Arab Charter on Human Rights ${ }^{18}$ (1997), - the main provisions of the international documents related to the right to higher education are repeated. The Continent of Asia and the Region of the Pacific do not have separate legal documents devoted to the protection of human rights; therefore, only international documents are applicable.

\section{THE CONTENT OF REQUIREMENT FOR HIGHER EDUCATION ACCESSIBILITY}

The concept of accessibility requires the elimination of any kind of discrimination when seeking higher education: legal and administrative hurdles, differentiation based on gender, social status, and economical status. The possible violations of this concept are many: it may be declining free transportation for the entire duration of studies by national or municipal institutions to inhabitants of

11 European Convention on Protection of Human Rights and Fundamental Freedoms, Official Gazette (1995, no. 40-987).

12 First Protocol of the European Convention of Human Rights and Fundamental Freedoms for ensuring some other rights and freedoms apart from those that are not foreseen in the latter, Official Gazette (1996, no. 15-386).

${ }_{13}$ European Social Charter (amended), adopted on October 18th, 1961, Official Gazette (2001, no. 491704).

${ }^{14}$ Charter or Fundamental Rights of European Union, adopted on December 7th, 2000 //

http://www.europarl.europa.eu/omk/omnsapir.so/pv2?PRG=DOCPV\&APP=PV2\&SDOCTA $=12 \& T X T L S T=1$ $\& T P V=D E F \& P O S=1 \& T y p e \_D o c=R E S O L \& D A T E=231002 \& D A T E F=021023 \& T Y P E F=A 5 \& P r g P r e V=T Y P E F @ A 5$ |PRG@QUERY|APP@PV2|FILE@BIBLIO02|NUMERO@332|YEAR@02|PLAGE@1\&LANGUE=EN (accessed November 4, 2010).

${ }^{15}$ African Charter on the Rights and Welfare of the Child, OAU Doc. CAB/LEG/24.9/49 // http://www.africa-

union.org/official_documents/Treaties_\%20Conventions_\%20Protocols/A.\%20C.\%200N\%20THE\%20RI GHT\%20AND\%20WELF\%200F\%20CHILD.pdf (accessed June 5, 2010).

16 African Charter on Human and Peoples' Rights, adopted on June 27th, 1981, came into force on October 21st, 1986, 1520 UNTS 217; 21 ILM 58 // http://www.achpr.org/english/_info/charter_en.html (accessed June 5, 2010).

17 American Convention on Human Rights, adopted on November 21st, 1969, came into force on June 18th, 1978, 1144 UNTS 123; 9 ILM 99 // http://www1.umn.edu/humanrts/oasinstr/zoas3con.htm (accessed June 5, 2010).

${ }_{18}$ The Arab Charter on Human Rights, adopted on September 15th, 1994, came into force in 2008 // http://www1.umn.edu/humanrts/instree/arabhrcharter.html (accessed June 5, 2010). 
distant regions who cannot physically reach an educational institution; the avoidance of creating respective legal and bureaucratic mechanisms that protect the right to education of vulnerable groups; ${ }^{19}$ or the imposition of legal and administrative hurdles that limit the possibility of certain persons to acquire an education. For example, in the case of Jehovah's Witnesses vs. Argentina, the Inter-American Human Rights Panel based on the American Convention on Human Rights has determined that legal obstacles to acquiring or continuing the education of children and grownups of the Jehovah confession breach almost all elements of the content of the right to education (availability, because the right to education is a breach of respect toward a certain group of people; acceptability - because Jehovah's witnesses are discriminated against on the grounds of religion, therefore the right of equal opportunity to education is breached; acceptability - because parents are not allowed to school their children according to their religious and moral beliefs; and adaptability - because the needs of a certain religious minority are disregarded in the educational process). ${ }^{20} \mathrm{~A}$ respective breach was determined in the case of Indigenous People in Guatemala ${ }^{21}$ when the government of Guatemala did not take all necessary legal and administrative measures to ensure the right to education of the indigenous people (Guatemala Indians) in its full scope: by not providing equal availability to acquire an education and by failing to establish a sufficient amount of schools in distant regions; by breaching the requirement of accessibility without taking into account all geographical, economic and ethnic circumstances while establishing schooling in the country; by failing to evaluate different cultural environments of students thereby breaching the requirement of acceptability; by failing to ensure the cultural right of the indigenous

\footnotetext{
${ }^{19}$ For example, in the famous case of Tanzania, the African Human Rights Commission has determined, that in certain states of Africa (Liberia, Mali, Nigeria, Swaziland, Uganda, Togo, Zambia) the applied practice, when girl who get pregnant prior to marriage or those who get married of school age and get pregnant, according to some legal norms are expelled from school because disobedience to certain norms of morality (yet according to the Marriage Act of Tanzania marriage is permitted to girls of 14 year of age) is discriminatory and breaches the right to acquire education. Due to this reason, one of the most common reasons that determines a large number of girls who do not finish school is early marriage. As an outcome of this case certain African states (Kenya, Zambia, Botswana, Guinea and Malawi) have legalized norms allowing the girls to continue education after the birth of the child (Racism, Racial Discrimination, Xenophobia and Related Intolerance in Education. The Case of Adolescent Girls in Tanzania // http://www.right-to-education.org/sites/r2e.gn.apc.org/files/Case_Study_Tanzania[1].pdf (accessed June 5, 2010)).

${ }^{20}$ Claim of the Jehovah's witnesses to the Commission was submitted because of the order of the president of Argentina which provided that all religious and educational centers of Jehovah's Witnesses are to be closed. Children whose parents confessed this religion were expelled from schools, and those who were educated at home could no longer take the appropriate state final exams. Students who confessed the religion of Jehovah's Witnesses were expelled from higher education institutions. Jehovah's Witnesses v. Argentina (1978) (Litigating Economic, Social and Cultural Rights: Legal Practitioners Dossier (COHRE: Geneva, 2006) //

http://www.cohre.org/store/attachments/COHRE\%20Legal\%20Practitioners\%20Dossier.pdf (accessed June 5, 2010)).

21 Racism, Racial Discrimination, Xenophobia and Related Intolerance in Education. The Case of Indigenous People in Guatemala, p 1 //

http://www.right-to-education.org/sites/r2e.gn.apc.org/files/Case_Study_Guatemala[1].pdf (accessed June 5, 2010).
} 
(a right to education in a native language) in the process of education thereby breaching the requirement of adaptability. It is noted that one of the most common breaches of the right of accessibility to higher education is related to legal and administrative measures adopted by the states which gives grounds to limiting equal opportunity to all to acquire higher education. ${ }^{22}$

World Declaration of Higher Education (1998) notes that the current greatest challenges encountered by the stated while trying to ensure the accessibility of higher education is providing equal conditions for enrolling into institutions of higher education; sufficient and adequate financing; globalization and internationalization of higher education; occupancy of the graduates in the labor market; quality of the studies and relevance of the study programs. It should also be noted that accessibility of higher education is directly linked with other parts of the educational chain, especially with secondary education. It is noted that an opportunity to acquire a higher education of preconditioning should occur before a potential student makes a relevant decision. Most common deciding factors appear to be economic and social environment, cultural and religious convictions, or the level of secondary education acquired. The accessibility of higher education should be linked with its current relevance and necessity, i.e., higher education should not be naturally self-oriented, although such tendency has been recently observed. Therefore, it is especially important to regulate the system of post secondary education and set separate goals of each branch according to the needs of society.

The requirement of accessibility and equal opportunities while acquiring education of any level can also be breached by legalizing disproportionate indirect costs on all levels of educations (for example, expenses for uniforms, books or other means of education). States are obligated to ensure free elementary education and gradually adopt free secondary and higher education. This criterion is related to choosing a model for financing of higher education and a state financing method; therefore, very concrete and precise requirements for the states are not determined. It is noted that in countries which are traditionally viewed as democratic violations of the requirement of accessibility of higher education are usually related to the policies of higher education financing and their implementation problems. It is agreed that diversifying of the sources of financing must be strengthened by ensuring the increasingly vast qualitative and institutional needs of higher education and implementing societal goals of higher education. The problem of insufficient accessibility in such a case is interpreted as a "threat of

\footnotetext{
${ }^{22}$ For example, in the case of Yean \& Bosico vs. Dominican Republic (2005) two girl of Haitian origin who were born in Dominican Republic because of certain legal provisions birth certificates were denied, which influenced further denial of the right to acquire any kind of education (see website: http://www.right-toeducation.org/node/183 (accessed June 5, 2010)).
} 
social rejection" ${ }^{23}$, i.e., inaccessibility of higher education may also determine future social exclusion of an individual in spheres of professional development, occupation, employment.

The Pact of Economic, Social and Cultural Rights which provides the most comprehensive approach towards the right to education with respect to its content scope, where the right to higher education is defined under two conditions: higher education must be equally accessible to all based on individual capacities and by all means (legal, administrative, economic). Additional obligation to the state parties is to gradually implement free higher education. Although, it is noted, that the right to education is primarily related to the capacities of its holder, i.e., it is not naturally granted to everyone (just as is the case with absolute rights, for example, the right not to be tortured or the right to proper legal representation). Those possessing relevant capacities may apply for state support while realizing their right to higher education (if the state has foreseen such support based on its economic capacities and legal regulation). Those who only have the "means" (i.e., financial resources), but do not possess sufficient capacities, may utilize the means by covering part or full costs for their tuition. It is noted that such persons must acquire "capacities" first with the help of financial means, which would, in turn, allow that person to compete with others regarding the right to free higher education. In a democratic society - and that is the only setting where higher education can serve its mission and fulfill societal expectations - such interpretation of higher education is considered the basis of social justice and human rights implementation in the field of education.

\section{ACCESSIBILITY OF HIGHER EDUCATION IN LITHUANIA}

Lithuania is directly impacted by the social, practical and legal problems that burden accessibility to the right to higher education. The most relevant issues while discussing accessibility to higher education are: the opportunity for persons of vulnerable social groups or financially disabled families to acquire higher education, as well as persons residing in distant regions and villages; the financial and daily problems of students that prevent them from completing their studies, and the related "loss" of those students; the opportunity for students of non-traditional age (35 years and older) to study or improve their competence; issues of the financing of higher education.

\footnotetext{
23 Antanas Juozas Bražiūnas, Petras Baršauskas ir Arūnas Degutis, "Aukštojo mokslo prieinamumas ir socialinis atmetimas [The accessibility and social denial of the higher education]": 31; in: Aukštojo mokslo sistemos ir didaktika. Konferencijos pranešimu medžiaga [The Systems and Didactics of the Higher Education. The Proceedings of the Conference] (Kaunas: Technologija, 1999), p. 31.
} 
The vast majority of the countries of the world have embedded the right to higher education at a constitutional level, by repeating fundamental provisions of international and regional documents in respect of this right. Most commonly it is provided by the constitutions that "everyone has a right to education" by supplementing this provision with obligations of different scopes on relevant levels of education (elementary, secondary, and higher). In the field of higher education it is usually meant to ensure equal opportunity for all to acquire higher education, which may be limited on the grounds of individual capacities. On the average onefifth of the world's countries ${ }^{24}$ necessarily provide and ensure on a constitutional level the right of all citizens to cost-free higher education.

The constitutional provision of Lithuania, which grants the right to acquire free higher education in institutions of higher education ${ }^{25}$ to excellent students, is unique, albeit extremely questionable and ambiguous. The right embedded in Article 41 of the Constitution is also supported by other laws of Republic of Lithuania: Article 35 of the Law on Fundamentals of Protection of Children Rights of Republic of Lithuania states that "higher education must be accessible to every child based on capacities. Children of academic excellence of citizenship of Lithuania free education is granted in state institutions of higher education"26; Article 25.3 of the Law on Education of Republic of Lithuania determines that "Each citizen of Lithuania, foreigner with a right of permanent or temporary residence in Republic of Lithuania the state grants [...] accessibility of programs of special education, vocational, higher education institution or professional education"27, i.e., the accessibility of higher education is ensured; Article 3 of the Law on Higher Education of Republic of Lithuania (already invalid) provides that:

Persons who have acquired an education not lower than of a secondary level, have a right, according to their capacities, based on the provision of this Law to acquire higher education in institutions of higher education of Lithuania. An order of studies of citizens of foreign countries and persons without citizenship is determined by the Government. Higher education acquire in foreign higher education institutions is acknowledged by laws of Republic of Lithuania and other

\footnotetext{
${ }^{24}$ According to data of United Nations of 2010 there are 193 officially recognized states (see website: http://www.un.org/en/members/growth.shtml\#1990 (accessed November 7, 2010)).

25 The Article 41 of the Constitution of Lithuania foresees: "Higher education shall be accessible to everyone according to his individual abilities. Citizens who are good at their studies shall be guaranteed education at State schools of higher education free of charge" (The Constitution of the Republic of Lithuania, Official Gazette (1992, no. 33-1014)).

${ }^{26}$ Law on Fundamentals of Children Rights' Protection of the Republic of Lithuania, Official Gazette (1996, no. 33-807).

27 Law on Education of the Republic of Lithuania, Official Gazette (1991, no. 23-593) [as amended by the Law of Amendment of the Law on Education of Republic of Lithuania, Official Gazette (2003, no. 632853)].
} 
legal acts, and order prescribed by international agreements of Republic of Lithuania. ${ }^{28}$

Article 52 of the Law of Academics and Studies of the Republic of Lithuania provides that "Persons having no lower than secondary education are accepted by way of competition to an institution of higher education, for integral studies of a first level, based on results of academic excellence, entrance exams or other criteria set by institution of higher education." ${ }^{29}$

The legal regulation of accessibility of higher education in Lithuania is based on a constitutional obligation of the state to provide free higher education to all citizens demonstrating academic excellence, i.e., it presupposes an obligation on the part of the state to create the preconditions for the realization of this right. This constitutional provision should be explained and interpreted with other constitutional imperatives. By ensuring the accessibility of higher education according to individual capacities, Article 29 of the Constitution-with its provision that all persons are equal before law, court and other state institutions, that human rights cannot be infringed and privileged because of gender, race, nationality, language, origin, social status, religion, conviction or opinion-must be amended. This provision also means that one cannot set requirements for those who seek to acquire higher education which would not be based on their own capacities, but according to some other criteria. It should be noted that state institutions have an obligation to set requirements that fall within the scope of the constitutional principle of equality to those who seek higher education. Also they have to ensure that such requirements are avoided by institutions of higher education. The law has to provide a legal regulation which would ensure that every person could seek higher education based on individual capacities. Nevertheless, it should also be noted that the accessibility of all to higher education based on individual capacities naturally does not mean a form of universality (Ruling of the Constitutional Court, February $\left.14^{\text {th }}, 2002\right)^{30}$.

The most questionable and complex constitutional obligation of a state is to ensure free education in state higher education institutions to citizens of proven academic excellence. The content and scope of this obligation was analyzed on

\footnotetext{
${ }^{28}$ Law on Higher Education of the Republic of Lithuania, Official Gazette (2000, No. 27-715) [invalid as of 2009-05-12].

${ }^{29}$ Law on Education and Science of the Republic of Lithuania, Official Gazette (2009, no. 54-2140).

30 The Ruling of the Constitutional Court of the Republic of Lithuania of the $14^{\text {th }}$ of January, 2002, "On the compliance of The Republic of Lithuania Law on Approving the Financial Indicators of the 2001 State Budget and Budgets of Local Governments (wording Of 19 December 2000), The Republic of Lithuania Law on The Approval of Indicators Determining the Amount and Leveling of Revenues of Local Governments Budgets for 2001, 2002 and 2003 and Article 16 of The Republic of Lithuania Law on the State Regulation of Economic Relations in Agriculture with the Constitution of The Republic of Lithuania," Official Gazette (2002, no. 5-186).
} 
multiple occasions by the Constitutional Court in cases of constitutional justice. ${ }^{31}$ The Constitutional Court has determined that the constitutional imperative for a state to ensure the right to free higher education for each citizen of proven academic excellence has to be interpreted by taking into account the balance between the rightful interest of a person and the needs of the state. The financial capabilities of the state (and the capabilities to finance higher education) are not and cannot be limitless. A constitutional provision that higher education is accessible to all according to the capacities of each individual cannot be interpreted as an obligatory provision of the state by means of the state to ensure the ambitions for higher education of anyone capable of completing the work, thereby undermining the needs and capacities of the society and state (Ruling of the Constitutional Court, February $\left.14^{\text {th }}, 2002\right)$. Therefore, according to the

${ }^{31}$ The Decision of the Constitutional Court of the Republic of Lithuania of the $18^{\text {th }}$ of December, 2009, "On the Construction of the provisions of items 6.1, 6.2 and 7 of chapter III of the Reasoning part of the Ruling of the Constitutional Court of the Republic of Lithuania of 14 January 2002," Official Gazette (2009, no. 151-6798); The Ruling of the Constitutional Court of the Republic of Lithuania of the $20^{\text {th }}$ of March, 2008, "On the compliance of the provision of the list of the agricultural enterprises and organisations not subject to privatisation approved by Resolution of the Government of the Republic of Lithuania No. 540 'On the Approval of the List of the Agricultural Enterprises and Organisations Not Subject to Privatisation' (wording of 27 February 1992) of 9 December 1991 with Paragraph 1 of article 23 of the Constitution of the Republic of Lithuania, the constitutional principle of a state under the rule of law, and with the provision of Article 1 of the Republic of Lithuania law 'On the Procedure and Conditions of the Restoration of the Rights of Ownership of Citizens to the Existing Real Property' (wording of 18 June 1991), as well as on the compliance of the list of the agricultural enterprises and organisations not subject to privatisation approved by Resolution of the Government of the Republic of Lithuania No. 540 'On the approval of the list of the agricultural enterprises and organisations not subject to privatisation' (wording of 14 May 1999) of 9 December 1991, Resolution of the Government of The Republic of Lithuania No.579 'On allocation of a land lot and on amending the targeted purpose of the land use' of 14 May 1999 and Resolution of the Government of The Republic of Lithuania No.266 'On partial amendment of Government Resolution No. 1026: 'On users of the land allotted to scientific and educational establishments and transferred to state specialised seed-growing and stock-breeding farms, special-purpose stock-breeding companies and on establishing the size of land lots used by these users' of 13 August 1998' of 8 March 2001 with Paragraphs 1 and 3 of Article 23 of the Constitution of the Republic of Lithuania, the constitutional principle of a state under the rule of law and with the provision of the preamble (wording of 1 July 1997) to the Republic of Lithuania Law on the Restoration of the rights of ownership of citizens to the existing real property," Official Gazette (2008, no. 34-1225); The Decision of the Constitutional Court of the Republic of Lithuania of the $28^{\text {th }}$ of October, 2009, "On the Construction of the Provision of Item 13 of Chapter II of the Reasoning Part of the Ruling of the Constitutional Court of the Republic of Lithuania of 20 March 2008," Official Gazette (2009, no. 1305652); The Ruling of the Constitutional Court of the Republic of Lithuania of the $27^{\text {th }}$ of June, 1994, "On the compliance of the norms of the Law of the Republic of Lithuania On Privatization of Apartments, establishing the privatization of hostel rooms in the institutions of higher education, with the Constitution of the Republic of Lithuania," Official Gazette (1994, no. 50-948); The Ruling of the Constitutional Court of the Republic of Lithuania of the $20^{\text {th }}$ of February, 2008, "On The Compliance of the Qualification Requirements of Higher Education in Law for the Persons who Wish to Hold, Under Procedure Established By Laws, the Position of a Judge Approved by Government of The Republic of Lithuania Resolution No. 1568 'On Approving the Qualification Requirements of Higher Education in Law for the Persons who Wish to Hold, under Procedure Established by Laws, the Position of a Judge' of 4 October 2002 with Paragraph 1 (wordings of 24 January 2002, 18 May 2004, 1 June 2006) of Article 51 of the Republic of Lithuania Law on Courts and Paragraph 1 of Article 5 of The Republic of Lithuania Law On the Entry into Force and Implementation of the Law on Amending the Law On Courts, "Official Gazette (2008, no. 23-852); The Ruling of the Constitutional Court of the Republic of Lithuania of the $7^{\text {th }}$ of June, 2007, "On the Compliance of Paragraph 3 (wording of 11 November 2004) of Article 3.194 of the Civil Code of The Republic of Lithuania with The Constitution of The Republic of Lithuania," Official Gazette (2007, no. 652529); The Ruling of the Constitutional Court of the Republic of Lithuania of the $5^{\text {th }}$ of February, 2002, "On the Compliance of Paragraph 5 of Article 8, Paragraph 3 of Article 9, Paragraph 3, Items 10, 11 and 12 of Paragraph 5 of Article 22, Items 1, 2 and 5 of Paragraph 1, Paragraphs 2 And 7 of Article 24, Paragraph 4 of Article 42, Article 60, Paragraph 1of Article 61, Paragraph 1of Article 62 and Paragraphs 1 and 2 of Article 65 of The Republic of Lithuania Law On Higher Education with the Constitution of The Republic of Lithuania," Official Gazette (2002, no. 14-518). 
Constitutional Court, a constitutional provision which provides that citizens of academic excellence are granted free higher education in state higher education institutions cannot be interpreted as such, which would supposedly suggest that by means of a state budget the Constitution grants free higher education in state higher education institutions to all citizens of academic excellence, no matter the conditions of their acceptance, i.e., also including those citizens of academic excellence who did not fall within the number of allotted student places, the previously announced number of which complies with the requirement of the state to finance preparation of a certain amount of relevant specialists, and also to those who have been accepted to study in that state institution of higher education on their own means.

The above mentioned constitutional provision is to be interpreted as one which embeds an obligation of the state by means of its budget to grant free higher education only to those citizens of academic excellence enrolled in state higher education institutions, who study according to the need of specialists of relative fields (spheres) determined by the needs of the state. The support of higher education has to be regulated by way of legal acts so that tuition expenses of citizens of academic excellence enrolled in state higher education institutions, who study according to the needs of specialists of relative fields (spheres), would in no form burden the students themselves (Ruling of the Constitutional Court, March $20^{\text {th }}, 2008$ ).

However, the text of the Constitution itself and its grammatical structure explicitly point out the obligation of the state to grant the right to free higher education to all those citizens of demonstrated academic excellence. In essence this means that the right to free higher education can depend neither on the form of studies nor the sphere. Therefore a provision determining paid studies in the form of part-time and night-time studies raises the issue of its legitimacy. This is also supported by the OECD Report on Higher Education of 2007, where systems of higher education of 21 countries were analyzed (among those Poland, Estonia, Norway, Finland, Russia, Belgium, and others). A report on the system and its management of higher education in Poland states that:

While part of the students in state higher institution do not pay for their tuition, other students in similar study programs pay the full price [...] present distribution of the tuition price is of a discriminatory nature. Therefore policy of tuition price should be expanded in such a way that the tuition price would be 
lower than the present tuition, which is paid by the students enrolled in study places that are not financed by the state. ${ }^{32}$

Avoiding the dispute regarding constitutional jurisprudence and the Constitutional Court, a conclusion can be made that such an interpretation of the constitutional provision by the court regarding ensuring free higher education to citizens of academic excellence is inevitable trying to lighten the financial burden of the state in the field of higher education, especially under increasingly vast demands for higher education. Therefore, the legal regulatory imperfections of this aspect are buried in the constitutional provision itself, which, in turn, should be revised.

Most discussions and doubts were raised and still remain regarding the obligation embedded in the Constitution to grant the right to free higher education to persons of precisely academic excellence. For a long time the notion of "academic excellence" remained undefined by the Law of Higher Education; therefore, during the seven years of its duration and application it was constantly interpreted and explained. In official constitutional doctrine the Constitutional Court revealed the content of the notion of "academic excellence": a citizen of academic excellence is considered one who "demonstrates academic excellence, i.e., his studies comply with the set criteria of academic excellence" (Ruling of the Constitutional Court, January $\left.14^{\text {th }}, 2002\right)$; the criteria that determine if a person is to be considered of academic excellence, therefore, according to the Constitution, are set by law (Ruling of the Constitutional Court, June $7^{\text {th }}, 2007$ ). These criteria have to be determined in advance, clear, objective, transparent-they cannot stray from the constitutional concept of academic excellence, nor from such a concept of academic excellence as comes from social experience within society, and nor may it undermine the universally acceptable and individually comprehensible meaning of the word "excellence".

By amending Article 60 the gap in the Law of Higher Education, which did not provide the criteria for academic excellence, was supposedly filled. This amendment of December 21, 2001 set forth that:

Students of academic excellence are granted free education - their tuition is covered by the state. Student of academic excellence are considered $30 \%$ of each study program of each semester, selected each semester according to the best study results; tuition of no less than $50 \%$ of full time students, selected by way of competition of the higher institution, is covered by the state. Each year

\footnotetext{
32 Oliver Fulton, Paulo Santiago, Charles Edquist, Elaine El-Khawas, and Elsa Hackl, OECD Reviews of Tertiary Education. Poland (OECD, 2007) // http://www.oecd.org/dataoecd/23/31/39321279.pdf (accessed November 16, 2010).
} 
the government decides which part of the student body according to the study programs and forms is granted full tuition by the state. ${ }^{33}$

However, such legal regulation was also faulty and unconstitutional, because:

Criteria set by the law, according to which a person is considered to be of an academic excellence cannot be formal, it is also not permitted to in advance foresee a certain number of supposedly "citizens of academic excellence" - an absolute or relative amount, i.e., quota, because it is impossible to exactly foresee how many students shall or shall not demonstrate academic excellence. Setting of similar quotas would completely disrupt the constitutional concept of academic excellence. On one hand there might be a lot larger number of citizens of academic excellence than a priori foreseen by the quota, therefore some citizens whose academic performance, as it universally agreed, is undoubtedly considered excellent would not fall within the scope of this quota; in such cases the state would fail to comply with its constitutional obligation to finance all students of academic excellence. On the other hand, there might be a smaller number of citizens of academic excellence than a priori foreseen by the quota, however, the state would anyway have to finance from its own resources these citizens who have accidentally fallen within the scope of this quota, whose academic performance, as it universally agreed, would not be considered as excellent; in such cases the state would use its resources without constitutional reasoning and justification in light of society. ${ }^{34}$

According to the text of Article 40 of the Constitution citizens have to be granted free education if their academic performance corresponds to the set criteria of academic excellence (Decision of the Constitutional Court, December 18th, 2009). These criteria of academic excellence (after the Constitutional Court

33 The Law on Amendment and Supplementation of the Article 2, Section II title, Articles 14, 15, 17, 27, $28,29,37,39,41,47,48,54,56,57,58,59,60,61,62,63,66,67$, and on Invalidation of the Articles $18,64,65$ and 68 of the Law on Higher Education of The Republic of Lithuania, Official Gazette (2002, no. 3-75).

${ }^{34}$ The Ruling of the Constitutional Court of the Republic of Lithuania of the $20^{\text {th }}$ of March, 2008, "On the compliance of the provision of the list of the agricultural enterprises and organisations not subject to privatisation approved by Resolution of the Government of the Republic of Lithuania No. 540 'On the Approval of the List of the Agricultural Enterprises and Organisations Not Subject to Privatisation' (wording of 27 February 1992) of 9 December 1991 with Paragraph 1 of article 23 of the Constitution of the Republic of Lithuania, the constitutional principle of a state under the rule of law, and with the provision of Article 1 of the Republic of Lithuania law 'On the Procedure and Conditions of the Restoration of the Rights of Ownership of Citizens to the Existing Real Property' (wording of 18 June 1991), as well as on the compliance of the list of the agricultural enterprises and organisations not subject to privatisation approved by Resolution of the Government of the Republic of Lithuania No. 540 'On the approval of the list of the agricultural enterprises and organisations not subject to privatisation' (wording of 14 May 1999) of 9 December 1991, Resolution of the Government of The Republic of Lithuania No.579 'On allocation of a land lot and on amending the targeted purpose of the land use' of 14 May 1999 and Resolution of the Government of The Republic of Lithuania No.266 'On partial amendment of Government Resolution No. 1026: 'On users of the land allotted to scientific and educational establishments and transferred to state specialised seed-growing and stock-breeding farms, special-purpose stock-breeding companies and on establishing the size of land lots used by these users' of 13 August 1998' of 8 March 2001 with Paragraphs 1 and 3 of Article 23 of the Constitution of the Republic of Lithuania, the constitutional principle of a state under the rule of law and with the provision of the preamble (wording of 1 July 1997) to the Republic of Lithuania Law on the Restoration of the rights of ownership of citizens to the existing real property," Official Gazette (2008, no. 34-1225). 
declared that determining quotas of students of academic excellence by law breaches the constitutional provision of the right to free education) were for the first time explicitly identified only on June 26th, 2008, in an amendment of Article 60 of the Law on Higher Education, which states that:

Students of academic excellence of state higher institutions, except those foreseen in Article 61 of this Law $^{35}$, are granted free education. Students of academic excellence are considered those who have passed all academic subjects, and whose grade average per semester is not lower than evaluation "eight" on a ten scale grade evaluation according to the study results evaluation system set by the Government or other authorized institution. ${ }^{36}$

That the amendment of this article finally set clear definitions for the criteria of academic excellence was a positive step; however, the principle of determining of an "excellent" evaluation itself is disputable. A student may pass easy subjects without difficulty and receive the highest evaluative mark of "excellent" ("ten" in a ten scale system), yet pass another subject with considerable difficulty and receive only a "sufficient" evaluation ("six" on a ten scale system) and he will still be considered a student of academic excellence. But in this case it is important that legislators finally carried out an obligation set forth by the Constitutional Court in 2002, namely, to set clear, distinct and transparent criteria for academic excellence which, in turn, empowered the better exercise of the constitutional right to free higher education for persons who comply with the requirement embedded in the Constitution.

After completing the reform of the financing of higher education in 2009, interpretation of the right of accessibility of higher education has changed in part. Article 70 of the Law on Education and Science states that:

Priority to the state financed study positions of the integrated first stage studies is granted to applicants according to their capabilities that are determined by the results of the final exams, academic performance, other results and special

\footnotetext{
35 The Article 61 Paragraph 1 of the Law on Higher Education (wording of 2008, June 26): "1. For studies at the State Higher School the tuition price, determined by the higher education institution, shall be paid by: 1) persons enrolled under the same or lower stage which they have graduated from a state university, degree program, if not more than half of the study program credits were paid the full price, exception shall be made in cases established by the Government, 2) persons at one time enrolled in two or more of the same graduate programs, if their studies according to at least one of these programs are fully or partly paid for by state funds (they pay for the second and further study programs), and 3 ) foreign nationals, if the international treaties of the Republic of Lithuania or other laws provide otherwise, 4) persons, according to the results of accession, outside the study sites in which enrolled students full or partially paid for by state funds."

${ }^{36}$ The Law on Amendment and Supplementation of the Articles 22, 23, 25, 47, 56, 58, 59, 60, 61 of the Law on Higher Education of the Republic of Lithuania, Official Gazette (2008, no. 73-2798). "Good at studies" are presumed being students who do not have academic debts and a grade point average of study per semester is a rating of not less than "eight" in the system of ten-point rating scale, determined by the Government or the authorized institution (Order by the Minister of Science and Education No. ISAK-2194 "Regarding the Confirmation of the evaluation system of study results," Official Gazette (2008, no. 86-3437)).
} 
capabilities. The list of best performing graduates of the secondary level is formed by the order prescribed by the Ministry of Education and Science; Only those person may apply to the integrated first stage studies whose academic performance results are not lower than the minimum indicators set forth by the Ministry of Education and Science. ${ }^{37}$

By such legal regulation the constitutional provision regarding the right to acquire free higher education for those of excellent academic performance may be distorted, because a "list of the best" is formed which does not necessarily encompass only those students who comply with the criteria of academic excellence set forth by the decisions of the Constitutional Court, and invalidates the amendment of the Law Of Higher Education. The list of students according to their achievements and academic results is formed based on objective and concrete criteria set by the order of the Minister of Science and Education ${ }^{38}$ : the score of the applicant is counted and the list of the best is formed from the persons seeking that their tuition be covered from the resources of the state budget. The order of the list, however, is determined by way of comparative method, i.e., by comparing the score results of the persons. Therefore the achievements of the persons in the queue who are later granted state financing for their education do not necessarily have to be evaluated as "good" ("eight" on a ten scale system) in an absolutely objective sense. The achievements become "good" by subjectively comparing the scores of the applicants of higher institutions. Also, the real value of the evaluation criteria (the competitive score) according to which a student later receives a student "package" is not clear, i.e., what evaluation score applied in the higher education institution does a competitive score represent. For example, the competitive score of all those accepted to the higher education institutions differed from 11,32 relative units (Vilnius Pedagogical University) to 20,33 relative units (Vilnius Gediminas University of Technology). ${ }^{39}$

Neither laws nor other normative acts clearly define a provision that the right to continue free education of those who have already been accepted to an institution of higher education and those who study is related with "good" academic performance throughout the whole process of higher education. In other words, the criteria of academic excellence are changed by the new legal regulation. Article 70 of the Law on Education and Sciences states that:

A person whose first stage integral studies are financed by the state loses the state financing after two years of the studies, in case of continuous studies -

\footnotetext{
${ }^{37}$ Law on Education and Science of the Republic of Lithuania, supra note 29.

38 Order by the Minister of Science and Education No. ISAK-1021 "Regarding the 2009 Description Order of Formation of the List of Best Graduates of the Secondary Education Level," Official Gazette (2009, no. 58-2257).

${ }^{39}$ Education. 2009 (Vilnius: Department of Statistics, 2010), p. 27.
} 
after completing half of the studies, if during the respective period the result average is more than $20 \%$ lower than the result average of the respective program and form of the higher institution of the same respective period. A person who loses state financing for the studies has to pay the tuition fee set by the institution of higher education, and his place in the state financed studies is occupied by another person of academic excellence. ${ }^{40}$

The situation is complicated and equivocal when a person receiving state financing for higher education studies academically performs on an average level, but his result average is not lower than the $20 \%$ general course average (the average level of academic performance in the course may also be quite low). Therefore this person is still granted state financing. Such legal regulation might be favorable for those who are enrolled in an institution of higher education, but it is dubious in light of social justice and constitutionality.

\section{CONCLUSIONS}

A right to education is commonly interpreted as an economic, social, and cultural right, which influences its implementation because obligations of the states in light of the rights of the aforementioned sphere are rather ambiguous and conditional, related as they are to economic capacities of the states and the adoption of progressive rights. Therefore economic, social, and cultural rights are often referred to as quasi-rights, which lack imperative measures for their implementation, and which, in turn, results in more frequent discussion regarding the right to education and inter alia breach of the right to education in scientific and human right protection institutions, rather than legal institutions. The complexity of the implementation of the right to higher education is influenced by formulated provisions of this right in various international and regional human rights documents, as well as the Constitution of the Republic of Lithuania. Obligations set forth for the states are quite broad, yet expressed in quite abstract and declarative terms. Therefore, based on an initiative of various international human rights protection organizations, an analysis of the right to education (including the right to higher education) was carried out. The study found that the content and scope of this right was formulated as it is currently used by international and regional human rights courts and quasi-legal institutions, breaches the right to higher education. The framework of the content of the right to higher education is based on the criteria of availability, accessibility, acceptability and adaptability. The requirement of accessibility is the most important in light of higher education. Regarding the accessibility of the higher education in Lithuania the conclusion can

\footnotetext{
${ }^{40}$ Law on Education and Science of the Republic of Lithuania, supra note 29.
} 
be drawn that the complexity of accessibility of higher education in Lithuania is still very relevant and unresolved. Continuous changes in the legal regulation and the vast number of interpretations of the right of accessibility of higher education have destabilized the system of higher education: they do not ensure current and future positive expectations of students; they discredit higher education as a social phenomenon; they devaluate the concepts of higher education as public and private good. Legal acts formalizing the reform of higher education also raise the question as to the full reasoning and constitutionality of their provisions. The constitutional provision regarding free education in state higher education institutions is itself questionable and possibly amendable.

\section{BIBLIOGRAPHY}

1. Almqvist, Jessica. Human Rights, Culture and the Rule of Law. Oxford and Portland, 2005.

2. Bražiūnas, Antanas Juozas, Petras Baršauskas ir Arūnas Degutis. "Aukštojo mokslo prieinamumas ir socialinis atmetimas [The accessibility and social deniail of the higher education]." In: Aukštojo mokslo sistemos ir didaktika. Konferencijos pranešimu medžiaga [The systems and didactics of the higher education. The proceedings of the conference]. Kaunas: Technologija, 1999.

3. Education. 2009. Vilnius: Department of Statistics, 2010.

4. EFA Global Monitoring Report 2009. Overcoming inequality: why governance matters. UNESCO Publishing, Oxford University Press, 2009 // http://www.unesco.org/en/efareport/reports/2009-governance/ (accessed November 7, 2010).

5. Fulton, Oliver, Paulo Santiago, Charles Edquist, Elaine El-Khawas, and Elsa Hackl. OECD Reviews of Tertiary Education. Poland. OECD, 2007 // http://www.oecd.org/dataoecd/23/31/39321279.pdf (accessed November 16, 2010).

6. Litigating Economic, Social and Cultural Rights: Legal Practitioners Dossier. COHRE: Geneva, 2006 // http://www.cohre.org/store/attachments/COHRE\%20Legal\%20Practitioners\% 20Dossier.pdf (accessed June 5, 2010).

7. Racism, Racial Discrimination, Xenophobia and Related Intolerance in Education. The Case of Adolescent Girls in Tanzania // http://www.right-toeducation.org/sites/r2e.gn.apc.org/files/Case_Study_Tanzania[1].pdf (accessed June 5, 2010). 
8. Racism, Racial Discrimination, Xenophobia and Related Intolerance in Education. The Case of Indigenous People in Guatemala //

http://www.right-to-

education.org/sites/r2e.gn.apc.org/files/Case_Study_Guatemala[1].pdf (accessed June 5, 2010).

9. World Education Report 2000. The Right to Education. Towards education for all throughout life. World Conference on Education for All Meeting Basic Learning Needs (Jomtien, Thailand; March 5-9, 1990). Paris: UNESCO Publishing, 1994.

10. World Declaration on Higher Education for the Twenty - First Century: Vision and Action and Framework for Priority Action for Change and Development in Higher Education. 1998 //

http://www.unesco.org/education/educprog/wche/declaration_eng.htm (accessed November 4, 2010).

\section{LEGAL REFERENCES}

1. African Charter on the Rights and Welfare of the Child. OAU Doc. CAB/LEG/24.9/49 //

http://www.africa-

union.org/official_documents/Treaties_\%20Conventions_\%20Protocols/A.\%20

C. \%200N\%20THE\%20RIGHT\%20AND\%20WELF\%200F\%20CHILD.pdf (accessed June 5, 2010).

2. African Charter on Human and Peoples' Rights. Adopted on June 27, 1981; came into force on October 21, 1986. 1520 UNTS 217; 21 ILM 58 // http://www.achpr.org/english/_info/charter_en.html (accessed June 5, 2010).

3. American Convention on Human Rights. Adopted on November 21, 1969; came into force on June 18, 1978. 1144 UNTS 123; 9 ILM 99 //

http://www1.umn.edu/humanrts/oasinstr/zoas3con.htm (accessed June 5, 2010).

4. Charter or Fundamental Rights of European Union. Adopted on December 7, $2000 / /$

http://www.europarl.europa.eu/omk/omnsapir.so/pv2?PRG=DOCPV\&APP=PV $2 \& S D O C T A=12 \& T X T L S T=1 \& T P V=D E F \& P O S=1 \& T y p=\_D o c=$ RESOL\&DATE $=231$ 002\&DATEF=021023\&TYPEF=A5\&PrgPrev=TYPEF@A5|PRG@QUERY|APP@PV2 |FILE@BIBLIO02|NUMERO@332|YEAR@02|PLAGE@1\&LANGUE=EN (accessed November 4, 2010).

5. Convention on the Rights of the Child. Official Gazette, 1995, no. 60-1501. 
6. European Convention on Protection of Human Rights and Fundamental Freedoms. Official Gazette, 1995, no. 40-987.

7. European Social Charter (amended). Adopted on October 18, 1961. Official Gazette, 2001, no. 49-1704.

8. First Protocol of the European Convention of Human Rights and Fundamental Freedoms for ensuring some other rights and freedoms apart from those that are not foreseen in the latter. Official Gazette, 1996, no. 15-386.

9. Law on Fundamentals of Children Rights' Protection of the Republic of Lithuania. Official Gazette, 1996, no. 33-807.

10. Law on Higher Education of the Republic of Lithuania. Official Gazette, 2000, no. 27-715 [invalid as of 2009-05-12].

11. Law on Education and Science of the Republic of Lithuania. Official Gazette, 2009, no. 54-2140.

12. Law on Education of the Republic of Lithuania. Official Gazette, 1991, no. 23593 [as amended by the Law of Amendment of the Law on Education of Republic of Lithuania. Official Gazette, 2003, no. 63-2853].

13. Order by the Minister of Science and Education No. ISAK-1021 "Regarding the 2009 Description Order of Formation of the List of Best Graduates of the Secondary Education Level". Official Gazette, 2009, no. 58-2257.

14. Order by the Minister of Science and Education No. ISAK-2194 "Regarding the Confirmation of the Evaluation System of Study Results". Official Gazette, 2008, no. 86-3437.

15. The Arab Charter on Human Rights. Adopted on September 15, 1994; came into force in $2008 / /$

http://www1.umn.edu/humanrts/instree/arabhrcharter.html (accessed June 5, 2010).

16. The Constitution of the Republic of Lithuania. Official Gazette, 1992, no. 331014.

17. The Decision of the Constitutional Court of the Republic of Lithuania of the $18^{\text {th }}$ of December, 2009, "On the Construction of the provisions of items 6.1, 6.2 and 7 of chapter III of the Reasoning part of the Ruling of the Constitutional Court of the Republic of Lithuania of 14 January 2002". Official Gazette, 2009, no. 151-6798.

18. The Decision of the Constitutional Court of the Republic of Lithuania of the $28^{\text {th }}$ October, 2009, "On the Construction of the Provision of Item 13 of Chapter II of the Reasoning Part of the Ruling of the Constitutional Court of the Republic of Lithuania of 20 March 2008". Official Gazette, 2009, no. 1305652. 
19. The International Covenant on Economic, Social and Cultural Rights. Official Gazette, 2002, no. 77-3290.

20. The Law of Amendment and Supplementation of the Articles 22, 23, 25, 47, 56, 58, 59, 60, 61 of the Law on Higher Education of the Republic of Lithuania. Official Gazette, 2008, no. 73-2798.

21. The Law on Amendment and Supplementation of the Article 2, Section II title, Articles 14, 15, 17, 27, 28, 29, 37, 39, 41, 47, 48, 54, 56, 57, 58, 59, 60, 61, $62,63,66,67$, and on Invalidation of the Articles 18, 64, 65 and 68 of the Law on Higher Education of the Republic of Lithuania. Official Gazette, 2002, no. 3-75.

22. The Ruling of the Constitutional Court of the Republic of Lithuania of the $14^{\text {th }}$ of January, 2002, "On the compliance of The Republic of Lithuania Law on Approving the Financial Indicators of the 2001 State Budget and Budgets of Local Governments (wording Of 19 December 2000), The Republic of Lithuania Law on The Approval of Indicators Determining the Amount and Leveling of Revenues of Local Governments Budgets for 2001, 2002 and 2003 and Article 16 of The Republic of Lithuania Law on the State Regulation of Economic Relations in Agriculture with the Constitution of The Republic of Lithuania". Official Gazette, 2002, no. 5-186.

23. The Ruling of the Constitutional Court of the Republic of Lithuania of the $20^{\text {th }}$ of March, 2008, "On the Compliance of the Provision of the List of the Agricultural Enterprises and Organisations not Subject to Privatisation Approved by Resolution of the Government of the Republic of Lithuania No. 540 'On the Approval of the List of the Agricultural Enterprises and Organisations not Subject to Privatisation' (wording of 27 February 1992) of 9 December 1991 with Paragraph 1 of article 23 of the Constitution of the Republic of Lithuania, the Constitutional Principle of a State under the Rule of Law, and with the Provision of Article 1 of the Republic of Lithuania Iaw 'On the Procedure and Conditions of the Restoration of the Rights of Ownership of Citizens to the Existing Real Property' (wording of 18 June 1991), as well as on the Compliance of the List of the Agricultural Enterprises and Organisations not Subject to Privatisation Approved by Resolution of the Government of the Republic of Lithuania No. 540 'On the approval of the list of the agricultural enterprises and organisations not subject to privatisation' (wording of 14 May 1999) of 9 December 1991, Resolution of the Government of The Republic of Lithuania No.579 'On Allocation of a Land Lot and on Amending the Targeted Purpose of the Land Use' of 14 May 1999 and Resolution of the Government of The Republic of Lithuania No.266 'On Partial Amendment of Government 
Resolution No. 1026: 'On Users of the Land Allotted to Scientific and Educational Establishments and Transferred to State Specialised SeedGrowing and Stock-Breeding Farms, Special-Purpose Stock-Breeding Companies and on Establishing the Size of Land Lots Used by these Users' of 13 August 1998' of 8 March 2001 with Paragraphs 1 and 3 of Article 23 of the Constitution of the Republic of Lithuania, the Constitutional Principle of a State under the Rule of Law and with the Provision of the Preamble (wording of 1 July 1997) to the Republic of Lithuania Law on the Restoration of the Rights of Ownership of Citizens to the Existing Real Property". Official Gazette, 2008, no. 34-1225.

24. The Ruling of the Constitutional Court of the Republic of Lithuania of the $27^{\text {th }}$ of June, 1994, "On the Compliance of the Norms of the Law of the Republic of Lithuania on Privatization of Apartments, Establishing the Privatization of Hostel Rooms in the Institutions of Higher Education, with the Constitution of the Republic of Lithuania". Official Gazette, 1994, no. 50-948.

25. The Ruling of the Constitutional Court of the Republic of Lithuania of the $20^{\text {th }}$ of February, 2008, "On the Compliance of the Qualification Requirements of Higher Education in Law for the Persons who Wish to Hold, under Procedure Established by Laws, the Position of a Judge Approved by Government of the Republic of Lithuania Resolution No. 1568 'On Approving the Qualification Requirements of Higher Education in Law for the Persons who Wish to Hold, under Procedure Established by Laws, the Position of a Judge' of 4 October 2002 with Paragraph 1 (wordings of 24 January 2002, 18 May 2004, 1 June 2006) of Article 51 of the Republic of Lithuania Law on Courts and Paragraph 1 of Article 5 of The Republic of Lithuania Law on the Entry into Force and Implementation of the Law on Amending the Law On Courts". Official Gazette, 2008, no. 23-852.

26. The Ruling of the Constitutional Court of the Republic of Lithuania of the $7^{\text {th }}$ of June, 2007, "On the Compliance of Paragraph 3 (wording of 11 November 2004) of Article 3.194 of the Civil Code of the Republic of Lithuania with the Constitution of the Republic of Lithuania". Official Gazette, 2007, no. 65-2529.

27. The Ruling of the Constitutional Court of the Republic of Lithuania of the $5^{\text {th }}$ of February, 2002, "On the Compliance of Paragraph 5 of Article 8, Paragraph 3 of Article 9, Paragraph 3, Items 10, 11 and 12 of Paragraph 5 of Article 22, Items 1, 2 and 5 of Paragraph 1, Paragraphs 2 And 7 of Article 24, Paragraph 4 of Article 42, Article 60, Paragraph 1 of Article 61, Paragraph 1 of Article 62 and Paragraphs 1 and 2 of Article 65 of the Republic of Lithuania Law On 
Higher Education with the Constitution of the Republic of Lithuania". Official Gazette, 2002, no. 14-518.

28. UNESCO Convention against Discrimination in Education. 429 UNTS 93 // http://www.unesco.org/education/pdf/DISCRI_E.PDF (accessed June 8, 2010).

29. Universal Declaration of Human Rights. Official Gazette, 2006, no. 68-2497. 